\title{
SERTULARIA FASTIGIATA LINNAEUS, 1758 (POLYZOA): PROPOSED SUPPRESSION UNDER THE PLENARY POWERS. Z.N.(S.) 1862
}

\section{By J. S. Ryland (Dept. of Zoology, University College of Swansea, Wales)}

1. This application deals with the nomenclature of two somewhat similar species in the polyzoan genus Bugula and, in effect, proposes the conservation of the names used for them by Hincks in the 'British Marine Polyzoa' (1880) and Ryland in the 'British species of Bugula' (1960). The species are:

(a) B. plumosa (Pallas): with spirally arranged branches, buff coloured in life and when dried; and distributed from the Mediterranean through western Europe, possibly reaching southern Norway, but certainly rare in northern Britain;

(b) B. purpurotincta Norman: tufted, but branches not spiral, drying a purplish colour; and distributed from northern Britain into Arctic latitudes.

2. Sertularia fastigiata was introduced by Linnaeus $(1758: 815)$ with short diagnosis and references to Ray and to Ellis. The reference to Ellis (1755:33, pl. 18; the Soft-feathered Coralline) is particularly important. Harmer (1930: 81-84) has established that 41 of the 44 species of Sertularia included by Linnaeus in Systema Naturae (ed. 10) " are based solely or principally on Ellis ". $S$. fastigiata is one of these. Ellis' work was outstanding for its time, especially in the excellence of its plates. Pl. 18 in conjunction with his description establishes that the Soft-feathered Coralline, and, therefore, $S$. fastigiata Linnaeus, is the species known in current literature as Bugula plumosa (Pallas).

3. Ellis $(1755: 33)$ gave the following diagnosis for the Soft-feathered Coralline: Corallina cellifera erecta ramosissima tenerrima \& plumosa. Pallas (1766: 66), presumably because he judged the adjective plumosa to be more appropriate to Ellis' diagnosis, substituted it in place of the name fastigiata proposed by Linnaeus. Thus, under his genus Cellularia, he introduced C. plumosa with references to Ray and Ellis and to Sertularia fastigiata Linnaeus.

It thus seems clear beyond any doubt that plumosa Pallas (1766) is a junior synonym of fastigiata Linnaeus (1758).

4. Fabricius $(1780: 445)$ recorded Sertularia fastigiata Linnaeus from Greenland. The identity of Fabricius' species is a matter for doubt (see Norman, $1868: 219$ ); but the question is fortunately unimportant in the present context, for it cannot have been Linnaeus' species (see para. 1 (a), Bugula plumosa).

5. In the ensuing years, European writers used either of the names fastigiata and plumosa (see synonymy given by Johnston, $1838: 294$ ). The material available to some of these authors, however, did not belong to fastigiata, but to the more boreal species later to be named Bugula purpurotincta (para. 1 (b)). Thus the actual specimens on which Johnston based his accounts of Acamarchis plumosa (1838 : 294) and Cellularia plumosa (1847 : 341), and Dalyell (1847: 
236) his description of Cellularia fastigiata, belonged to the more boreal species. Alder (1856: 149), however, distinguished the two species, and applied the name fastigiata to the more northerly distributed of the two.

6. Norman (1868:149) quite properly introduced the new name purpurotincta for Bugula fastigiata Alder, recognising that Sertularia fastigiata Linnaeus " is our B. plumosa".

7. The name fastigiata evidently remained associated with the boreal species, for Hincks (1880:89) lapsed into using it in the discussion of the species he had introduced as Bugula purpurotincta. No doubt it was mainly for this reason that he employed Pallas' name plumosa for the more southern "Soft-feathered Coralline", although he did query the identification of $S$. fastigiata L. with Bugula plumosa.

8. All recent writers (e.g. Ryland, 1960; Prenant \& Bobin, 1966) have followed Hincks in calling the more southern species Bugula plumosa (Pallas).

9. Ryland (1960) correctly named the boreal species Bugula purpurotincta Norman; but Kluge (1962), and Prenant \& Bobin (1966) following him, referred to this species as Bugula fastigiata (Dalyell). Dalyell $(1847: 236)$, in fact, (incorrectly) named his species Sertularia fastigiata Linnaeus (para. 5 above).

10. The name fastigiata cannot be used for Bugula purpurotincta Norman, as it is properly the name of the species currently known as B. plumosa. On the other hand, having been recently though incorrectly applied to B. purpurotincta, it would be confusing in the extreme to transfer this name to another species; especially to replace a name so well-established as B. plumosa. The only satisfactory solution appears to be for the International Commission on Zoological Nomenclature to suppress the name Sertularia fastigiata Linnaeus.

11. The International Commission on Zoological Nomenclature is therefore requested:

(a) to suppress for purposes of the Law of Priority, but not for the Law of Homonymy, the specific name fastigiata Linnaeus, 1758, as introduced in the binomen Sertularia fastigiata;

(b) to place on the Official List of Specific Names in Zoology: plumosa Pallas, 1766, as published in the binomen Cellularia plumosa;

(c) to place on the Official List of Specific Names in Zoology: purpurotincta Norman, 1868, as published in the binomen Bugula purpurotincta;

(d) to place on the Official Index of Rejected and Invalid Specific Names in Zoology: fastigiata Linnaeus, 1758, as published in the binomen Sertularia fastigiata (as suppressed under the plenary powers in (a) above).

\section{REFERENCES}

Alder, J. 1856. Trans. Tyneside Nat. Field Club, $3: 93-162$

DALYelL, J. G. 1847. Rare and Remarkable Animals of Scotland, 268 pp.

Ellis, J. 1755. Natural History of the Corallines, 103 pp.

FABRICIUS, O. 1780 . Fauna Groenlandica, 452 pp.

Harmer, S. F. 1930. Proc. Linn. Soc. London, 141 : 68-118

Hincks, T. 1880 . British Marine Polyzoa, $601 \mathrm{pp.}$

JoHNSTON, G. 1838 . British Zoophites, 341 pp.

- 1847. British Zoophytes, ed. 2, 488 pp.

KLUGE, G. A. $1962 . \quad$ Opred. Faune S.S.S.R., 76 : 1-584 
Linnaeus, C. 1758. Systema Naturae, ed. 10, 824 pp.

Norman, A. M. 1868. Q. Jl microsc. Sci., 8: 212-222

Pallas, P. S. 1766. Elenchus Zoophytorum, 451 pp.

Prenant, M., and Bobin, G. Faune Fr., 68 : 1-647

Ryland, J. S. 1960. Proc. zool. Soc. Lond., 134 : 65-105 


\section{$2 \mathrm{BHL}$ Biodiversity Heritage Library}

Ryland, J S. 1969. "Sertularia fastigiata Linnaeus, 1758 (Polyzoa): proposed suppression under the plenary powers. Z.N. (S.) 1862." The Bulletin of zoological nomenclature 25, 229-231. https://doi.org/10.5962/bhl.part.24005.

View This Item Online: https://www.biodiversitylibrary.org/item/44467

DOI: https://doi.org/10.5962/bhl.part.24005

Permalink: https://www.biodiversitylibrary.org/partpdf/24005

\section{Holding Institution}

Natural History Museum Library, London

\section{Sponsored by}

Natural History Museum Library, London

\section{Copyright \& Reuse}

Copyright Status: In copyright. Digitized with the permission of the rights holder.

License: http://creativecommons.org/licenses/by-nc-sa/3.0/

Rights: https://biodiversitylibrary.org/permissions

This document was created from content at the Biodiversity Heritage Library, the world's largest open access digital library for biodiversity literature and archives. Visit BHL at https://www.biodiversitylibrary.org. 